\title{
Apprehension in patient's mind: leading to myiasis
}

\author{
Ajay Aggarwal, Siddharth Pandey, Ashish Sharma, Ruchir Aeron
}

Department of Urology, King George's Medical University, Lucknow, Uttar Pradesh, India

\section{Correspondence to}

Dr Ajay Aggarwal, drajayaggarwal2004@gmail. com

Accepted 8 June 2018

\section{DESCRIPTION}

A 65-year-old man had a history of acute urinary retention for which suprapubic catheterisation (SPC) was performed, following failed attempts at per urethral catheterisation by a local practitioner 3 months previously. He also had a history of hesitancy and intermittency for the past 1 year. He now presented with maggots discharging from the SPC site (figures 1 and 2). On taking a detailed history, he mentioned lack of local hygiene due to fear of dislodgement of SPC. There was no history of diabetes mellitus, surgical intervention or immune-compromised status.

Per urethral catheterisation was attempted over a guide wire that was successful. Then his SPC was removed and turpentine oil was applied locally for maggots' expulsion. Later, an ultrasound abdomen was performed that suggested an enlarged prostate $(44 \mathrm{cc})$ with a prominent median lobe. SPC site wound was managed conservatively with regular dressings. Transurethral resection of the prostate was performed later for the enlarged prostate.

SPC is usually required when per urethral catheterisation is not possible in diseases such as stricture urethra, urethral calculus and so on. Other possible scenarios in which SPC is useful are urethrocutaneous fistula, penile gangrene, preoperatively to give urethral rest and so on. In tropical countries like India, local SPC site infection is more common due to warm and humid environment and low socioeconomic status which results in neglected SPC care and myiasis in extreme cases. In our patient, neglected local hygiene due to patient's apprehension led to myiasis.

Myiasis is a rare disease primarily caused by infestation of tissue by larvae of houseflies. It is frequently reported in vertebrates but is rare in humans. Various risk factors for myiasis are described including low socioeconomic status, immunocompromised state, physical debilitation and unhygienic living conditions. ${ }^{1}$ Myiasis can be classified anatomically into cutaneous myiasis, myiasis of external orifices (aural,

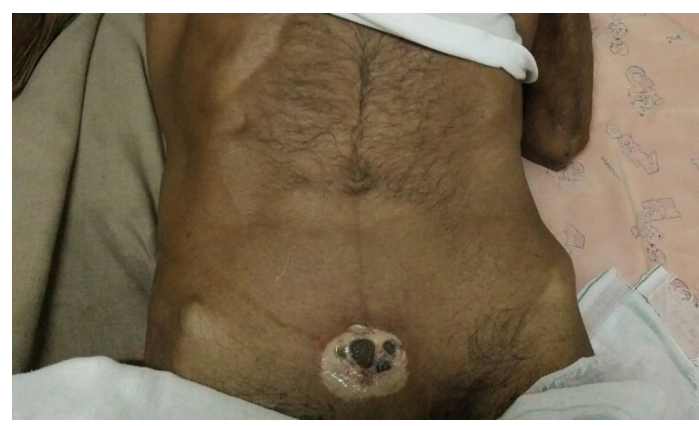

Figure 1 Clinical photograph of the patient showing the suprapubic catheterisation site wound with maggots inside it.

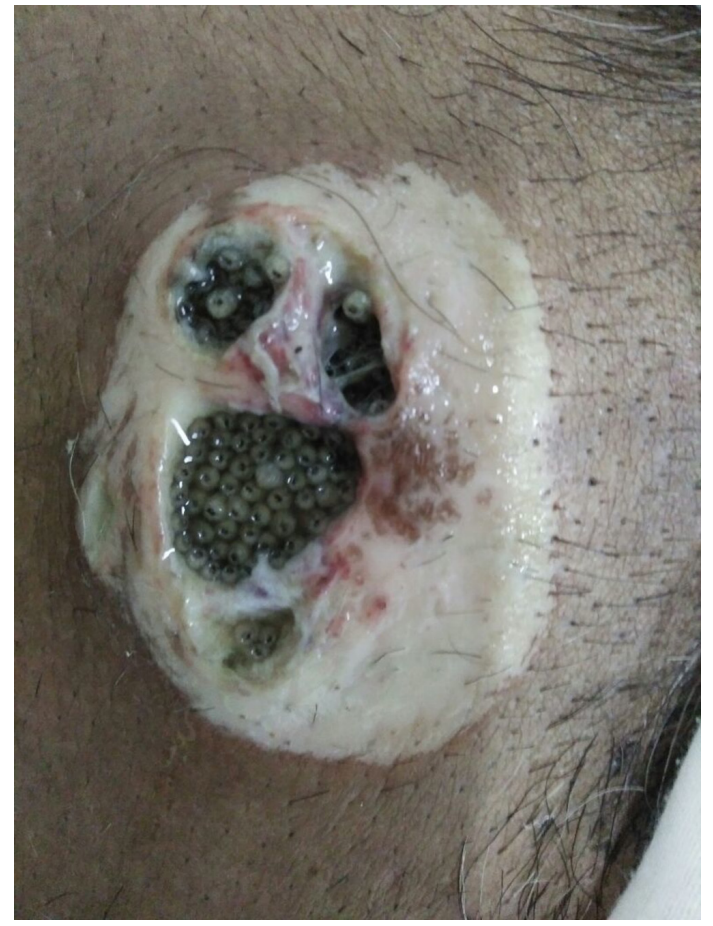

Figure 2 Clinical photograph showing closer view of the suprapubic catheterisation site wound with maggots.

ocular, nasal, oral, vaginal) or myiasis involving internal organs such as intestine or urinary tract. ${ }^{2}$ Treatment for myiasis as in our case involves mechanical removal of all visible larvae followed by local application of either turpentine oil, mineral oil, ether, chloroform, ethyl chloride, mercuric chloride, creosote, saline, phenol, calomel, olive oil or iodoforms, with antibiotic support to prevent secondary bacterial contamination. In some cases, extensive wound debridement may be required. Use of oral or topical ivermectin has also been described. ${ }^{3}$ This is followed by regular dressings and maintenance of personal hygiene.

\section{Learning points}

While suprapubic catheter insertion, patient should be properly advised regarding maintenance of local hygiene and suprapubic catheterisation (SPC) site wound care.

- Apprehension of SPC removal in patient's mind should be relieved by demonstrating selfretaining mechanism of Foley catheter.

- Treatment options for myiasis vary according to the affected site and primarily include expelling/ removal of maggots chemically/manually or using agents like ivermectin. 
Contributors AA and SP: concept, design, supervision, processing, writing manuscript and critical analysis. AS: supervision, processing, writing manuscript and critical analysis. RA: concept, supervision, writing manuscript and critical analysis.

Funding The authors have not declared a specific grant for this research from any funding agency in the public, commercial or not-for-profit sectors.

Competing interests None declared.

Patient consent Obtained.
Provenance and peer review Not commissioned; externally peer reviewed.

\section{REFERENCES}

1 Auluck A. Oral health of poor people in rural areas of developing countries. J Can Dent Assoc 2005:71:753-5.

2 Lim ST. Oral myiasis-a review. Singapore Dent J 1974;13:33-4.

3 Kumar SL, Manuel S, John TV, et al. Extensive gingival myiasis-diagnosis, treatment, and prevention. J Oral Maxillofac Pathol 2011;15:340.

Copyright 2018 BMJ Publishing Group. All rights reserved. For permission to reuse any of this content visit http://group.bmj.com/group/rights-licensing/permissions.

BMJ Case Report Fellows may re-use this article for personal use and teaching without any further permission.

Become a Fellow of BMJ Case Reports today and you can:

- Submit as many cases as you like

Enjoy fast sympathetic peer review and rapid publication of accepted articles

- Access all the published articles

Re-use any of the published material for personal use and teaching without further permission

For information on Institutional Fellowships contact consortiasales@bmjgroup.com

Visit casereports.bmj.com for more articles like this and to become a Fellow 